\title{
Treponema pallidum infection predicts sexually transmitted viral infections (hepatitis B virus, herpes simplex virus-2, and human immunodeficiency virus) among pregnant women from rural areas of Mwanza region, Tanzania
}

Gilbert Ng'wamkai ${ }^{1}$, Kalista V. Msigwa², Damas Chengula², Frank Mgaya², Clotilda Chuma', Betrand Msemwa ${ }^{3}$, Vitus Silago ${ }^{2}$, Mtebe Majigo ${ }^{4}$, Stephen E. Mshana ${ }^{2}$ and Mariam M. Mirambo ${ }^{2^{*}}$ (i)

\begin{abstract}
Background: Sexually transmitted infections (STIS) is a global health problem with increased risk and morbidities during pregnancy. This study investigated the magnitude of viral STIs among pregnant women from three rural hospitals/clinics providing antenatal care in Mwanza region, Tanzania.

Methods: Between February and May 2018, a total of 499 pregnant women were enrolled and tested for Human immunodeficiency virus (HIV), Herpes simplex virus-2 (HSV-2), Hepatitis B virus (HBV) and Hepatitis C virus (HCV) using rapid immunochromatographic tests and for syphilis using non-treponemal and treponemal antibody test.

Results: The median age of enrolled women was 25 (IQR: 22-31) years. Seventy eight (15.6, 95\% Cl: 12-18) of women tested had at least one sexually transmitted viral infection. Specific prevalence of HIV, HBV, HCV, HSV-2 lgG and HSV-2 IgM were found to be 25(5.0\%), 29(5.8\%), 2(0.4\%), 188(37.7\%) and 24(4.8\%), respectively. The odds of having viral infection was significantly high among women with positive T. pallidum serostatus (adjusted odd ratio (aOR): $3.24,95 \% \mathrm{Cl} ; 1.2-85)$. By multivariable logistic regression analysis, history of STls predicted HSV-2 IgM seropositivity (aOR: $3.70,95 \% \mathrm{Cl}: 1.43-9.62)$ while parity (aOR: 1.23, 95\%Cl: 1.04-1.46) predicted HBV infection and syphilis positive results (aOR: 8.63,95\%Cl: 2.81-26.45) predicted HIV infection.

Conclusion: A significant proportion of pregnant women in rural areas of Mwanza region has at least one sexually transmitted viral infection which is independently predicted by positive T. pallidum serostatus. The strengthening and expansion of ANC screening package to include screening of STIs will ultimately reduce the viral STIs among pregnant women hence reduce associated morbidities and mortalities.
\end{abstract}

Keywords: Herpes simplex-2, Hepatitis B, Hepatitis C, HIV, Mwanza, Rural

\footnotetext{
* Correspondence: mmmirambo@gmail.com

${ }^{2}$ Department of Microbiology and Immunology, Weill Bugando School of Medicine, Catholic University of Health and Allied sciences, P.O. Box 1464, Mwanza, Tanzania

Full list of author information is available at the end of the article
}

(c) The Author(s). 2019 Open Access This article is distributed under the terms of the Creative Commons Attribution 4.0 International License (http://creativecommons.org/licenses/by/4.0/), which permits unrestricted use, distribution, and reproduction in any medium, provided you give appropriate credit to the original author(s) and the source, provide a link to the Creative Commons license, and indicate if changes were made. The Creative Commons Public Domain Dedication waiver (http://creativecommons.org/publicdomain/zero/1.0/) applies to the data made available in this article, unless otherwise stated. 


\section{Background}

Sexually transmitted infections (STI) particularly those caused by viruses have been associated with a number of adverse pregnancy outcomes including stillbirth, spontaneous abortion, preterm births, prematurity, postpartum endometritis and low birth weight among other various long term sequelae in surviving neonates [1, 2]. Herpes simplex virus type 2 (HSV-2) is the main causative agent of genital ulcer diseases worldwide [3]. It can be transmitted vertically from mother to the fetus and it is highly prevalent in the sub-Saharan Africa whereby it has been found to cause severe illness to the neonates [4-7].

On the other side, a previous study reported that nearly $90 \%$ of pregnant women living with HIV in the world are from sub-Saharan Africa [8, 9]. Challenges associated with effective prevention of mother-to-child transmission of HIV (PMTCT) include adherence and failure in identifying HIV-infected mothers [8], making HIV still a problem in these countries. Regarding viral hepatitis, Hepatitis B virus (HBV) and hepatitis $\mathrm{C}$ viruses $(\mathrm{HCV})$ are major public health concern worldwide with high prevalence in the sub-Saharan Africa and Asia [10, 11]. It is estimated that, over 1 million deaths related to chronic liver disease are due to HBV [12]. Most of individuals in endemic areas are infected vertically or during childhood [10]. Similarly, $\mathrm{HCV}$ infection are common in many countries worldwide [11]. The World Health Organization (WHO) estimates that $3 \%$ of the world's populations are chronically infected with $\mathrm{HCV}$ with high prevalence reported in the subSaharan Africa [13, 14].

The current practice regarding antenatal screening in Tanzania includes routine screening of HIV and T. pallidum infections while the care for other STIs like HSV-2, HBV and HCV mostly rely on symptoms. Nevertheless, in many developing countries particularly in rural settings, it is uncommon to visit health facilities unless having signs and symptoms of disease and most of these STIs are asymptomatic [15]. Due to the current situation regarding antenatal screening of these infections in Tanzania, data regarding the magnitude of these infections among pregnant women in rural setting are scarce. Lack of these data hinders introduction of the appropriate strategies to prevent these infections especially in rural areas. This study was conducted to establish the magnitude of sexually transmitted viral infections among pregnant women in Tanzania. The data might help to come up with recommendations on the current screening protocol and control strategies.

\section{Methods}

\section{Study design and duration}

A cross sectional hospital based study involving 499 pregnant women attending three rural antenatal clinics
(Magu, Karume and Sengerema) in Mwanza region was conducted between February and May 2018.

\section{Study area}

The study was conducted in Sengerema, Ilemela and Magu districts in Mwanza region, Tanzania. (http:// www.jgid.org/viewimage.asp?img=JGlobalInfectDis_201 0_2_3_216_68530_u3.jpg). Mwanza is located in the North-Western zone of Tanzania, with a population of 2,772,509 [16]. Sengerema Designated Ditrict hospital (DDH) has a capacity of 320 beds and attends approximately 30-40 pregnant women daily at its antenatal clinic [17], it is located $60 \mathrm{~km}$ from Mwanza city. Magu District Hospital (MDH) is $60 \mathrm{~km}$ from Mwanza city and has capacity of 200 beds and attends approximately 3040 pregnant women daily in the antenatal clinic. Karume Health Centre (KHC) is located in Ilemela district $20 \mathrm{~km}$ from Mwanza city and serves about 20-30 pregnant women daily. The antenal atendance in Mwanza region in 2018 is about $73 \%$ with $83 \%$ delivery in health facilities (www.dhis.moh.go.tz).

\section{Study population and selection criteria}

All pregnant women at different ages and gestation ages attending at $\mathrm{KHC}$, Sengerema $\mathrm{DDH}$ and $\mathrm{MDH}$ antenatal clinics were included in the study after obtaining informed consent.

\section{Sample size estimation and sampling technique}

The sample was calculated by Kish Leslie formula for observational study [18] using the prevalence of $50 \%$ to get the minimum sample size of 384 participants, however, 499 pregnant women were enrolled. Purposive sampling was used to select the study areas and the study participants were enrolled serially as they come to a clinic until the desired sample size of that clinic was reached. The sample size from each clinic was calculated based on the proportion of women attending specific clinic daily.

\section{Data and samples collection}

A pre-tested structured data collection tool which comprised both open and close ended questions was used to collect required data (Additional file 1). Data collected included demographic and clinical data such signs and symptoms of STIs. Individual face to face interview was used to obtain these data from a study participant. Antenatal cards were reviewed to get information such as antenatal visits profile, gestation age and important antenatal investigations such as syphilis and HIV testing.

The first trimester was defined as $\leq 13$ weeks, second trimester $13-\leq 26$ weeks and third trimester more than 26 weeks of gestation. Data were collected by nurses in case the patient required special attention was reviewed 
by doctors present in the respective hospital or the $\mathrm{OB} /$ GY resident. About 4-5mls of venous blood sample was collected from each of enrolled participant and placed in plain vacutainer tubes (Becton, Dickinson and Company, USA). Samples were transported to the Catholic University of Health and allied sciences for processing. Sera were extracted and stored in cryovials at $-40 \mathrm{C}$ until analysis.

\section{Laboratory procedures}

Samples were tested as per national HIV diagnosis algorithm using SD Bioline and Unigold as previously, described [19] to establish HIV serostatus. Detection of HSV-2 virus specific IgM and IgG antibodies was done by using rapid immunochromatographic test as per manufacturer's instructions (Exact Diagnostic Devices -USA). The test has a sensitivity of $95 \%$ and specificity of $94.7 \%$. Hepatitis B surface antigen HBsAg (Accu-Tell, Beijing, China) and $\mathrm{HCV}$ antibodies were tested using rapid immunochromatography tests as per manufacturer's instructions (ACON laboratories, Inc., CA92121, USA). Syphilis was detected using non-treponemal test (Standard diagnosticsInc, Korea) and all positive samples were confirmed using Treponema pallidum Hemagglutination test (Chronolab systems, Barcelona, Spain).

\section{Data analysis}

Data collected were entered into a computer using Microsoft Office Excel 2007 and analyzed by using STATA version 13 (STATA Corp LP, USA). In the present study any patient with history of vaginal discharge or genital ulcer or clinically treated as case of STIs in the past was considered to have history of STIs. Presence of at least one viral infections was defined as being positive to HSV2 IgM antibodies or positive HIV status or positive $\mathrm{HBsAg}$ or positive $\mathrm{HCV}$ antibodies. Categorical variables (marital status, education level, occupation, history of STIs, use of condoms etc.) were summarized as proportions and were analyzed using the Pearson's Chi-square test to observe the significant differences in distribution of viral infections among various groups like age, education levels etc. Continuous variables (age, gestation age, parity, number of sexual partners etc.) were summarized as median with interquartile range. Univariable and multivariable logistic regression model was used to determine the factors associated with HSV-2, HIV and HBV positivity. Variables with $p$-value less than 0.2 on univariable regression model were subjected into the backward multivariable logistic regression analysis adjusted by age. Odds ratio and $95 \%$ confidence interval were noted. Variables with p-value of less than 0.05 were considered statistically significant.

\section{Results}

Sociodemographic, relationship and sexual history characteristics of 499 pregnant women attending ANCs in Mwanza - rural Tanzania

A total of 499 pregnant women with the median age of 25 (IQR: 22-31) years were enrolled. Of these women, 98, 200 and 201 were from Karume clinic (Ilemela), Magu district hospital and Sengerema district hospital, respectively. Most of the participants were in the second $257(49.5 \%)$ and third 222(46.5\%) trimesters with the median gestation age of 25(IQR: 20-32) weeks. Approximately two-thirds (63.9\%) had completed primary school while $(17.8 \%)$ of the women had never attended any formal school. The majority of women 464 (93\%) were married and more than half 277 (55.6\%) were peasants. Approximately more than half 266 (53.3\%) reported having more than one sexual partner in lifetime and less than one-fourth of women 109 (21.8\%) knew that their partner had other partner(s) outside of their relationship. Of the 499 participants, 20 (4\%) were T. pallidum (syphilis) seropositive (Table 1).

\section{History of STls symptoms and risk behaviour among 499 pregnant women attending ANCs in rural areas of Mwanza region Tanzania}

Among 499 pregnant women enrolled, 92 (18.4\%) were found to have history of STIs and almost half of the women 249 (49.9\%) reported a history of lower abdominal pain. A total of 174 (34.9\%), $109(21.8 \%)$ and 28 (5.6\%) women reported history of dysuria, dyspareunia and genital ulcers, respectively. In addition, more than three quarters $388(77.8 \%)$ of women reported no history of condom use during sex (Table 1).

\section{Prevalence of HSV-2, HIV, HBV and HCV among 499 pregnant women attending ANCs in Mwanza- rural Tanzania}

Seventy eight (15.6, 95\% CI: 12-18) of women tested, had at least one sexually transmitted viral infection. A total of $188(37.7,95 \%$ CI: $33-41)$ were found to be HSV-2 IgG seropositive while 24 (4.8 95\% CI: 2-6) wereHSV-2 IgM seropositive. On Wilcoxon Ranksum (Man Whitney) test there was no significant difference in age between those who were HSV-2 IgG seropositive and HSV-2 IgG seronegative (26, IQR: $21-31$ vs. 25, IQR: $22-31, p=0.455)$. However, the HSV-2 IgG seroprevalence was significantly high among women aged below 20 years compared to women aged above 20 years [45 (47.4\%) vs. 143(35.4), $p=0.030$ ]. In addition, 8 women who were HSV-2 IgG seropositive were found to have genital ulcer whereby 4 of them were T. pallidum (syphilis) seropositive. Regarding HSV-2 IgM seropositivity, there was no significant difference in age between 
Table 1 Sociodemographic, relationship, sexual characteristics and clinical signs among 499 pregnant women attending ANCs in Mwanza-rural Tanzania

\begin{tabular}{|c|c|c|c|c|c|}
\hline & \\
\hline Characteristics & Frequency/Median (IQR) & Percentages (\%) & Characteristics & Frequency/Median (IQR) & Percentages (\%) \\
\hline Age (years) & 25 [IQR: 22-25] & & H/Dyspareunia & & \\
\hline Gestation age (weeks) & 25[IQR:20-32] & & Yes & 109 & 21.84 \\
\hline Age of 1st sexual intercourse & 17[IQR16-18] & & No & 390 & 78.16 \\
\hline Parity & $1[\mathrm{IQR} 0-3]$ & & H/Lower abdominal Pain & & \\
\hline Number of sex partners & $2[\mathrm{IQR} 1-4]$ & & Yes & 249 & 49.90 \\
\hline Condom use & & & No & 250 & 50.10 \\
\hline Yes & 111 & 22.2 & H/Genital ulcer & & \\
\hline No & 388 & 77.8 & Yes & 28 & 5.61 \\
\hline Education level & & & No & 471 & 94.39 \\
\hline
\end{tabular}

$\begin{array}{lll}\text { Never attended } & 89 & 17.84 \\ \text { Primary } & 319 & 63.93\end{array}$

$\begin{array}{lll}\text { Secondary } & 91 & 18.24\end{array}$

Occupation

$\begin{array}{lll}\text { Peasant } & 227 & 55.51 \\ \text { House wife } & 79 & 12.83 \\ \text { Business/employed } & 143 & 28.66\end{array}$

Parity

$\begin{array}{lll}\text { Primigravida } & 130 & 26.05 \\ \text { Multipara } & 262 & 52.51 \\ \text { Grandmultipara } & 107 & 21.44\end{array}$

Gestation age

First trimmest $\quad 20 \quad 4.00$

Second trimester $\quad 257 \quad 51.50$

$\begin{array}{lll}\text { Third trimester } & 222 & 44.49\end{array}$

Marital status

Married 464

92.99

Not married

35

7.01

Partner has other women outside relationship

$\begin{array}{lll}\text { Yes } & 109 & 21.84 \\ \text { No } & 390 & 78.16\end{array}$

More than two Sexual partners

$\begin{array}{lll}\text { Yes } & 266 & 53.31 \\ \text { No } & 233 & 46.69 \\ \text { Syphilis status } & & \\ \text { Negative } & 479 & 95.99 . \\ \text { Positive } & 20 & 4.01 \\ \text { HNagina discharge } & & \\ \text { Yes } & 92 & 18.44 \\ \text { No } & 407 & 81.56 \\ \text { H/Dysuria } & & \\ \text { Yes } & 174 & 34.87 \\ \text { No } & 325 & 65.13\end{array}$

Table 1 Sociodemographic, relationship, sexual characteristics and clinical signs among 499 pregnant women attending ANCs in Mwanza-rural Tanzania (Continued)

IgM seropositive women and seronegative women (25, IQR: $22-28$ vs. 26 , IQR: $21-31, p=0.699$ ).

The prevalence of HBV was found to be $29(5.8,95 \%$ CI: 3.7-7.6). The median age of HBV positive women was 30 (IQR: 21-33) years compared to HBV negative women 25 (IQR: 22-31), $p=0.082$. The seroprevalence of HIV was 25(5.0, 95\% CI: 3.0-6.9). The median age of HIV seropositive women was significantly high compared to their counterparts [28 (IQR: 25-32) vs. 25 (IQR: 21-31), $p=0.032$ ]. Overall, seroprevalence of $\mathrm{HCV}$ were found to be $2(0.4,95 \% \mathrm{CI}: 0.2-0.5)$ (Fig. 1 ). These two patients were HIV, HBV, HSV IgM and syphilis negative but were positive for HSV IgG antibodies.

\section{Factors associated with HSV-2 IgG and HSV-2 IgM seropositivity among 499 pregnant women attending ANCs in Mwanza- rural Tanzania}

Regarding HSV-2 IgG seropositivity, on univariable analysis, only age at first sex (aOR: 0.917, 95\%CI: 0.84-0.99, $p=0.028$ ) was found to be associated with IgG seropositivity. However, the history of STIs (aOR: 1.45, 95\%CI: $0.99-2.12, p=0.053$ ) had borderline significance on multivariable analysis (Table 2). In addition, on univariable analysis, history of STIs (OR: 3.47, 95\% CI: 1.36-8.91, $p=0.009)$ was significantly associated with specific HSV2 IgM seropositivity and remained significant on multivariable logistic regression analysis (aOR: $3.70,95 \% \mathrm{CI}$ : 1.43-9.62, $p=0.007$ ) (Table 3).

\section{Factors associated with HBV and HIV among 499 pregnant women}

Increase in parity (aOR: $1.23,95 \% \mathrm{CI}: 1.04-1.46, p=$ $0.015)$ significantly predicted $\mathrm{HBsAg}$ positivity on multivariable logistic regression analysis (Table 4). Regarding HIV seropositivity, on univariable analysis, parity (OR: $1.2,95 \%$ CI: $1.08-1.51, p=0.03$ ), age (aOR: 1.06, 95\% CI: $1.00-1.13, p=0.044$ ), and positive syphilis serostatus (OR: 10.37, 95\% CI: 3.59-29.97, 


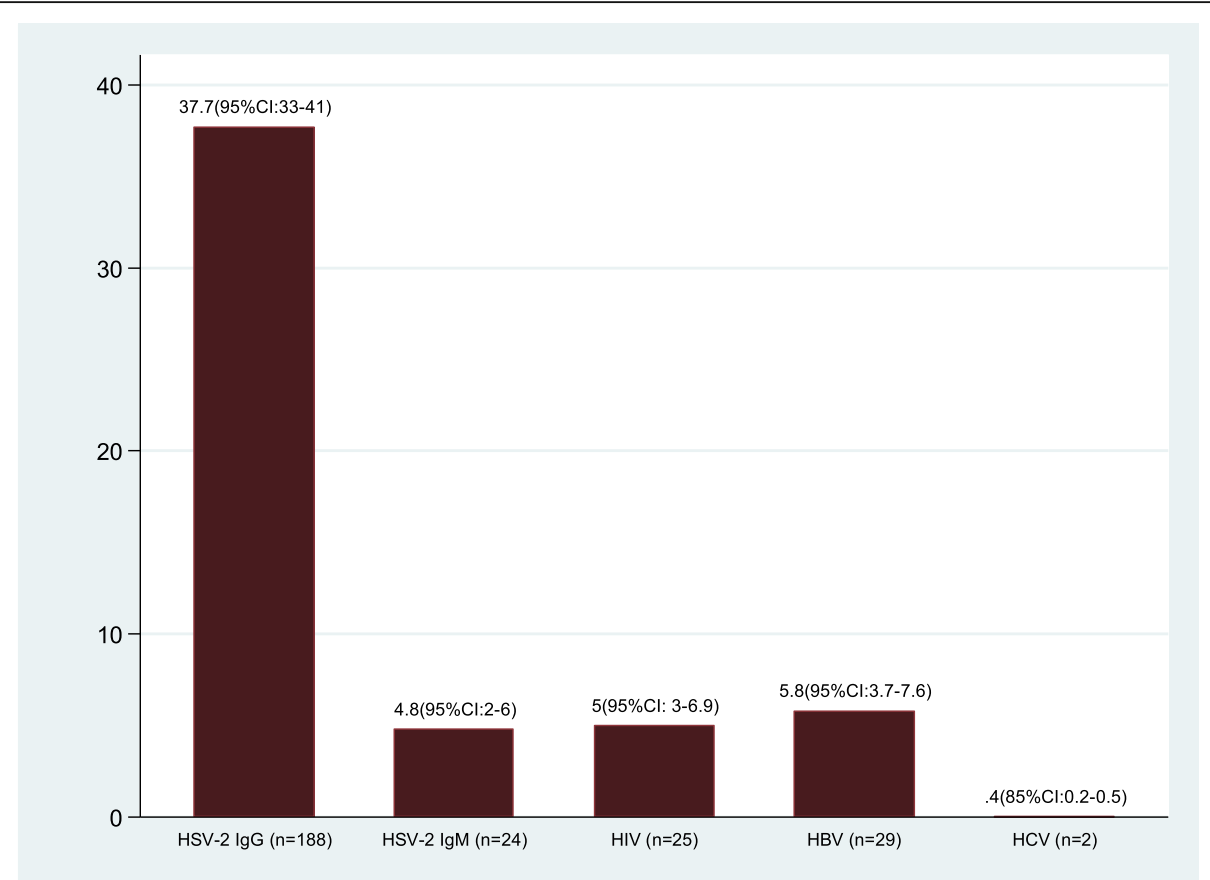

Fig. 1 Prevalence of sexually transmitted viral infections among 499(N) pregnant women in rural areas of Mwanza region. Letter " $n$ " refers to positive samples for each virus

$p<0.001)$ were found to be significantly associated with HIV seropositivity. Only positive syphilis serostatus (aOR: $8.63,95 \%$ CI: $2.81-26.45, p<0.001$ ) predicted HIV seropositivity (Table 5).

\section{Factors associated with at least one viral infections} among 499 pregnant women

The prevalence of viral STIs was significantly higher in T. pallidum seropositive women than seronegative women $(40 \%$ vs. $14.6 \%, p=0.004)$. Age, parity, education, marital status, syphilis serostatus were found to be significantly associated with at least one viral STIs (Table 6). Only positive syphilis serostatus (aOR: 3.25 , 95\% CI: 1.23-8.57, $p=0.016)$ independently predicted at least one viral infection (Table 6).

\section{Discussion}

Sexually transmitted infections are common cause of morbidities and adverse pregnancy outcomes among pregnant women worldwide with the high prevalence reported in low-income countries (LICs) [20]. This study assessed the prevalence of sexually transmitted viral infections (HIV, HSV-2, HBV and HCV) among pregnant women in rural areas of Mwanza region. In this study it was observed that a significant proportion of pregnant women in rural areas of Mwanza region had at least one sexually transmitted viral infections.

\section{Prevalence and factors associated with HSV-2} seropositivity among pregnant women in rural areas of Mwanza region

Overall seroprevalence of specific HSV-2 IgG and IgM antibodies among pregnant women in this study was high, which is similar to a previous study among adolescent pregnant women in the same settings [21]. Furthermore, this observation is similar to another study which was done in Ethiopia in the same population [22]. Moreover, in the current study, there was significant difference in HSV-2 IgG seroprevalence among women aged below 20 years compared to those aged above 20 years. When compared with a previous study by Hokororo et al, the IgG seroprevalence among women aged below 20 years in the current study was significantly high ( $p=$ $0.019)$ [21]. These findings are contrary to previous studies which showed that seroprevalence of HSV-2 tend to increase with age $[23,24]$. The possible explanation could be sensitivity and specificity of the test used in these studies whereby, in the current study rapid immunochromatographic test was used with sensitivity and specificity of 95 and $94.7 \%$, respectively. When compared to a previous study in Zimbabwe, the reported seroprevalence in the current study is slightly low; nevertheless, these data show that HSV-2 is common among pregnant women in Africa [22, 25]. In comparison to seroprevalence reported in middle and high income countries like India and Italy, the seroprevalence reported in the current study is indeed high [26, 27]. 
Table 2 Univariable and multivariable logistic regression analysis of the factors associated with specific HSV-2 IgG seropositivity among 499 pregnant women attending ANC's in Mwanza-rural Tanzania

\begin{tabular}{|c|c|c|c|c|c|}
\hline Characteristics & $\begin{array}{l}\text { HSV IgG } \\
\text { Seropositivity (\%) }\end{array}$ & Univariable & $P$-value & Multivariable & $P$-value \\
\hline Age & 26 [IQR 21-31] & $0.99[0.97-1.02]$ & 0.678 & $1.00[0.97-1.03]$ & 0.895 \\
\hline Parity & 1.5 [IQR 0-3] & 0.98 [1.089-1.076] & 0.676 & & \\
\hline Gestational age & 24 [IQR 20-32] & $0.99[0.97-1.02]$ & 0.562 & & \\
\hline Number sexual of partners & 2 [IQR 1-4] & $1.03[0.98-1.08]$ & 0.315 & & \\
\hline${ }^{*}$ Age at first sex & 17[IQR:15-18] & $0.917[0.84-0.99]$ & 0.028 & $0.92[0.85-1.00]$ & 0.056 \\
\hline \multicolumn{6}{|l|}{ *Occupation } \\
\hline Employed (143) & $46(32.17)$ & ref & & & \\
\hline Peasant (277) & 109(39.35) & $1.37[0.89-2.09]$ & 0.149 & $1.42[0.92-2.18]$ & 0.113 \\
\hline House wife (79) & $33(41.77)$ & $1.52[0.86-2.67]$ & 0.153 & $1.44[0.80-2.59]$ & 0.221 \\
\hline \multicolumn{6}{|l|}{ Education } \\
\hline Secondary (91) & $28(30.77)$ & ref & & & \\
\hline Primary (319) & $130(40.75)$ & $1.55[0.94-255]$ & 0.086 & & \\
\hline Never attended (89) & $30(33.71)$ & $1.44[0.61-2.14]$ & 0.673 & & \\
\hline \multicolumn{6}{|l|}{ Marital status } \\
\hline Married (464) & 171(36.85) & ref & & & \\
\hline Not married (35) & $17(48.57)$ & $1.62[0.81-3.22]$ & 0.171 & & \\
\hline \multicolumn{6}{|l|}{ *History of genital ulcer } \\
\hline No (452) & 175(38.72) & ref & & & \\
\hline Yes (47) & 13(27.66) & $0.61[0.31-1.18]$ & 0.140 & $0.53[0.26-1.06]$ & 0.074 \\
\hline \multicolumn{6}{|l|}{ Genital ulcers } \\
\hline Absent (471) & 180(38.22) & ref & & & \\
\hline Present (28) & $8(28.57)$ & $0.65[0.28-1.49]$ & 0.309 & & \\
\hline \multicolumn{6}{|l|}{ *History of STIS } \\
\hline No (261) & $90(34.48)$ & ref & & & \\
\hline Yes (238) & $98(41.18)$ & $1.33[0.93-1.91]$ & 0.124 & $1.45[0.88-2.12]$ & 0.053 \\
\hline \multicolumn{6}{|l|}{ *HIV status } \\
\hline Negative (474) & 182(38.40) & ref & & & \\
\hline Positive (25) & $6(24 \%)$ & $0.51[0.19-1.29]$ & 0.155 & $0.55[0.21-1.42]$ & 0.218 \\
\hline \multicolumn{6}{|l|}{ Syphilis status } \\
\hline Negative (479) & 178(37.16) & ref & & & \\
\hline Positive (20) & $10(50 \%)$ & $1.69[0.69-4.14)$ & 0.250 & & \\
\hline
\end{tabular}

${ }^{*}$ Age of first sex, occupation, history of genital ulcers, history of STIs and HIV status were subjected on multivariable analysis adjusted by age, ref = reference

This might be attributable to the improved health care, awareness and healthy seeking behavior in developed countries compared to rural areas of Tanzania and other low income countries. Compared to previous studies in Dar es salaam and Moshi which focused on urban population the findings are comparable to the current study $[28,29]$. However, the observed seroprevalence in the current study is slightly higher than what was reported in Manyara and Singida [21,30]. The differences could be explained by different diagnostic methods used where by the previous studies used non-commercial peptide- 55 Enzyme-linked immunosorbent assay.
Considering the fact that in Tanzania only HIV and syphilis are screened during antenatal visits, this calls for the need for policy makers to consider inclusion of HSV-2 screening in the Tanzanian antenatal package which overall will improve antenatal care in Tanzania. In this study about $5 \%$ of women were HSV-2 IgM seropositive indicating acute or recent infection which put unborn child at an increased risk of vertical transmission that can lead to neonatal herpes [5, 7]. This emphasizes the need of considering screening of HSV-2 during antenatal visits so that care can be taken in handling these women during delivery. Due to the nature of the current 
Table 3 Univariable and multivariable logistic regression analysis of the factors associated with specific HSV-2 IgM seropositivity among 499 pregnant women attending ANC's in Mwanza rural Tanzania

\begin{tabular}{|c|c|c|c|c|c|}
\hline Characteristics & $\begin{array}{l}\text { HSV IgM } \\
\text { Seropositivity \% }\end{array}$ & $\begin{array}{l}\text { Univariable } \\
\text { OR }(95 \% \text { Cl) }\end{array}$ & $P$ value & $\begin{array}{l}\text { Multivariable } \\
\text { OR }(95 \% \mathrm{Cl})\end{array}$ & $P$ value \\
\hline Age & 25[IQR:22-28] & $0.98[0.92-1.05]$ & 0.595 & $0.99[0.93-1.06]$ & 0.884 \\
\hline Parity & 1[IQR:0-3] & $0.93[0.75-1.16]$ & 0.515 & & \\
\hline Gestation age & 25.5[IQR:20-30] & $0.10[0.94-1.05]$ & 0.906 & & \\
\hline Number of sexual partner & $3[\mid \mathrm{QR}: 1-5]$ & $0.10[0.89-1.11]$ & 0.993 & & \\
\hline Age at first sex & 17[IQR:15-18] & $0.94[0.72-1.12]$ & 0.509 & & \\
\hline \multicolumn{6}{|l|}{ *Occupation } \\
\hline Employed (143) & $5(3.50 \%)$ & ref & & & \\
\hline Peasant (277) & 13(4.69\%) & $1.35[0.47-3.90]$ & 0.567 & $1.41[0.48-4.14]$ & 0.525 \\
\hline House wife (79) & $6(7.59 \%)$ & $2.27[0.67-7.69]$ & 0.188 & $2.29[0.66-7.10]$ & 0.192 \\
\hline \multicolumn{6}{|l|}{ Education } \\
\hline Secondary (91) & $2(2.2 \%)$ & ref & & & \\
\hline Primary (319) & $15(4.7 \%)$ & $2.20[0.49-9.78]$ & 0.302 & & \\
\hline Never attended (89) & $7(7.87 \%)$ & $3.80[0.77-18.81]$ & 0.102 & & \\
\hline \multicolumn{6}{|l|}{ *Marital status } \\
\hline Married (464) & $21(4.53 \%)$ & ref & & & \\
\hline Not married (35) & $3(8.5 \%)$ & $1.98[0.56-6.98]$ & 0.289 & $2.12[0.57-7.83]$ & 0.260 \\
\hline \multicolumn{6}{|l|}{ History of genital ulcer } \\
\hline No (452) & $23(5.1)$ & ref & & & \\
\hline Yes (47) & $1(2.1)$ & $0.41[0.1-3.07]$ & 0.312 & & \\
\hline \multicolumn{6}{|l|}{ Genital ulcers } \\
\hline Absent (471) & $24(5.1)$ & ref & & & \\
\hline Present (28) & $0(0.0)$ & omitted & omitted & & \\
\hline \multicolumn{6}{|l|}{ *History of STIs } \\
\hline No (261) & $6(2.30)$ & ref & & & \\
\hline Yes (238) & 18(7.56\%) & $3.47[1.36-8.91]$ & 0.009 & $3.7[1.43-9.62]$ & 0.007 \\
\hline \multicolumn{6}{|l|}{ HIV status } \\
\hline Negative (474) & $23(4.8)$ & ref & & & \\
\hline Positive (25) & $1(4.0)$ & $0.817[0.10-6.30]$ & 0.846 & & \\
\hline \multicolumn{6}{|l|}{ Syphilis status } \\
\hline Negative (479) & $23(4.8 \%)$ & ref & & & \\
\hline Positive (20) & $1(5.0 \%)$ & $1.04(0.13-8.13)$ & 0.968 & & \\
\hline
\end{tabular}

*Occupation, marital status and history of STIs were subjected on multivariable analysis adjusted by age

study these women were not followed up to establish outcomes of the newborns. Further studies to determine the outcomes of maternal HSV-2 infection are warranted in this setting. In addition, eight women who were HSV2 IgG seropositive were found to have genital ulcer whereby 4 of them were T. pallidum (syphilis) seropositive. This indicates that other STIs are also common among pregnant women in rural areas of Mwanza.

Among the factors studied in this study, a history of sexually transmitted infection was found to predict IgM seropositivity which is similar to the previous reports $[22,28,30]$. In the current study no significant association was established between HIV and HSV-2 seropositivity which is contrary to what was observed in the previous studies [31, 32]. This could be explained by a small number of HIV seropositive women in the current study.

\section{Prevalence and associated factors of HBsAg among pregnant women in rural areas of Mwanza city}

In this study the prevalence of HBsAg was found to be $5.8 \%$ which is almost three folds higher than a previous study in an urban areas of Moshi municipal which reported the prevalence of $2.0 \%$ and two folds higher than 
Table 4 Univariable and multivariable logistic regression analysis of the factors associated with specific HBsAg positivity among 499 pregnant women attending ANC's in Mwanza-rural Tanzania

\begin{tabular}{|c|c|c|c|c|c|}
\hline Characteristics & $\begin{array}{l}\text { HBsAg IgG } \\
\text { Seropositivity (\%) }\end{array}$ & Univariable & $P$ - value & Multivariable & $P$-value \\
\hline${ }^{*} \mathrm{Age}$ & 21 [IQR 21-33] & $1.06[1.00-1.12]$ & 0.034 & & \\
\hline Parity & 3 [IQR 1-5] & $1.2[1.08-1.51]$ & 0.003 & $1.23[1.04-1.46]$ & 0.015 \\
\hline Gestational age & 22 [IQR 20-32] & 0.99 [0.94-1.03] & 0.679 & & \\
\hline Number sexual of partners & 3 [IQR 1-5] & $1.04[0.96-1.12]$ & 0.304 & & \\
\hline Age at first sex & 17[IQR:15-20] & $1.02[0.97-1.06]$ & 0.319 & & \\
\hline \multicolumn{6}{|l|}{ Occupation } \\
\hline Employed (143) & $7(4.90)$ & ref & & & \\
\hline Peasant (277) & $21(7.58)$ & $1.59[0.66-3.84]$ & 0.299 & $1.4[0.57-3.42]$ & 0.460 \\
\hline House wife (79) & $1(1.27)$ & $0.24[0.03-2.06]$ & 0.197 & $0.30[0.03-2.52]$ & 0.269 \\
\hline \multicolumn{6}{|l|}{ Education } \\
\hline Secondary (91) & $4(4.40)$ & ref & & & \\
\hline Primary (319) & 19(5.96) & $1.37[0.46-4.15]$ & 0.570 & & \\
\hline Never attended (89) & $6(6.74)$ & $1.57[0.42-5.77]$ & 0.495 & & \\
\hline \multicolumn{6}{|l|}{ Marital status } \\
\hline Married (464) & $28(6.03)$ & ref & & & \\
\hline Not married (35) & $1(2.86)$ & $2.18[0.29-16.54]$ & 0.450 & & \\
\hline \multicolumn{6}{|l|}{ History of genital ulcer } \\
\hline No (452) & $27(5.97)$ & ref & & & \\
\hline Yes (47) & $2(4.26)$ & $0.70[0.16-3.03]$ & 0.634 & & \\
\hline \multicolumn{6}{|l|}{ Genital ulcers } \\
\hline Absent (471) & $28(5.94)$ & ref & & & \\
\hline Present (28) & $1(3.57)$ & $0.58[0.08-4.47]$ & 0.606 & & \\
\hline \multicolumn{6}{|l|}{ History of STIS } \\
\hline No (261) & 13(4.98) & ref & & & \\
\hline Yes (238) & $16(6.72)$ & 1.37 [0.65-2.92] & 0.408 & & \\
\hline \multicolumn{6}{|l|}{ HIV status } \\
\hline Negative (474) & $29(6.12)$ & ref & & & \\
\hline Positive (25) & $0(0.00)$ & Omitted & & & \\
\hline \multicolumn{6}{|l|}{ Syphilis status } \\
\hline Negative (479) & $28(5.85)$ & ref & & & \\
\hline Positive (20) & $1(5)$ & $0.85[0.11-6.56)$ & 0.874 & & \\
\hline
\end{tabular}

*Age was not subjected in the multivariable analysis due to its collinearity with parity

another study in urban areas of Mwanza city which reported the prevalence of $3.8 \%$ [33,34]. Our results show that $\mathrm{HBV}$ is more prevalent in rural areas than urban areas of Tanzania. The possible explanation could be exposure to the risk factors which might be associated with knowledge gap of possible routes of HBV transmission. As reported previously [35-37], most of rural residents do not have enough knowledge on HBV transmission as compared to urban counterparts. In comparison to previous reports in African countries; Sierra Leone, Mali, Kenya, Nigeria and Burkina Faso which reported prevalence of $6.2,8.0,8.8,11$ and $17.2 \%$ respectively, the prevalence reported in the current study is low [38-42]. The possible geographical variations could play a role in these differences and exposure to the risk factors as well as different tests used in these studies. The current study used rapid immunochromatographic test with sensitivity and specificity of $>98 \%$ which might be different in other studies.

Regarding the factors associated with HBV infection, in the current study only parity was found to independently predict HBV positivity. Increase in age was found to be associated with HBV infections on univariable analysis, this observation is inconsistent to a previous study 
Table 5 Univariable and multivariable logistic regression analysis of the factors associated with specific HIV seropositivity among 499 pregnant women attending ANC's in Mwanza-rural Tanzania

\begin{tabular}{|c|c|c|c|c|c|}
\hline Characteristics & $\begin{array}{l}\text { HIV } \\
\text { Seropositivity (\%) }\end{array}$ & Univariable & $P$ - value & Multivariable & $P$-value \\
\hline Age & 28 [IQR 25-32] & $1.06[1.00-1.13]$ & 0.044 & $1.02[0.93-1.13]$ & 0.571 \\
\hline *Parity & 3 [IQR 1-5] & $1.2[1.08-1.51]$ & 0.003 & $1.09[0.80-1.47]$ & 0.559 \\
\hline Gestational age & 22 [IQR 20-32] & $0.99[0.94-1.03]$ & 0.679 & & \\
\hline Number sexual of partners & 3 [IQR 1-5] & $1.04[0.96-1.12]$ & 0.304 & & \\
\hline Age at first sex & 17[IQR:15-20] & $1.02[0.97-1.06]$ & 0.319 & & \\
\hline \multicolumn{6}{|l|}{ Occupation } \\
\hline Employed (143) & $7(4.9)$ & ref & & & \\
\hline Peasant (277) & $16(5.8)$ & $1.19[0.47-2.94]$ & 0.707 & & \\
\hline House wife (79) & $2(2.5)$ & $0.50[0.10-2.48]$ & 0.401 & & \\
\hline \multicolumn{6}{|l|}{ Education } \\
\hline Secondary (91) & $3(3.3)$ & ref & & & \\
\hline Primary (319) & $15(4.7)$ & $1.45[0.40-5.11]$ & 0.566 & & \\
\hline Never attended (89) & $7(7.9)$ & $2.50[0.62-10.00]$ & 0.194 & & \\
\hline \multicolumn{6}{|l|}{ Marital status } \\
\hline Married (464) & $28(6.03)$ & ref & & & \\
\hline Not married (35) & $1(2.86)$ & $2.18[0.29-16.54]$ & 0.450 & & \\
\hline \multicolumn{6}{|l|}{ History of genital ulcer } \\
\hline No (452) & $22(4.9)$ & ref & & & \\
\hline Yes (47) & $3(6.4)$ & $1.33[0.38-4.63]$ & 0.651 & & \\
\hline \multicolumn{6}{|l|}{ Genital ulcers } \\
\hline Absent (471) & $22(4.7)$ & ref & & & \\
\hline Present (28) & $3(10.7)$ & $2.44[0.68-8.73]$ & 0.167 & $1.65[0.40-6.80]$ & 0.485 \\
\hline \multicolumn{6}{|l|}{ History of STIS } \\
\hline No (261) & 13(4.98) & ref & & & \\
\hline Yes (238) & $16(6.72)$ & 1.37 [0.65-2.92] & 0.408 & & \\
\hline \multicolumn{6}{|l|}{ *Syphilis status } \\
\hline Negative (479) & $19(4.0)$ & ref & & & \\
\hline Positive (20) & $6(30)$ & $10.37[3.59-29.97]$ & $<0.001$ & $8.63[2.81-26.45]$ & $<0.001$ \\
\hline
\end{tabular}

*Parity and syphilis status were subjected on multivariable analysis adjusted by age

in Sudan which did not find any association of HBV infection with age among pregnant women [43]. Nevertheless, the findings in the current study are in line with other studies in Burkina Faso, Nigeria and Moshi municipal [34, 40, 41]. As previously reported prevalence of viral infections tends to increase with increase in age $[44,45]$ hence aged women who are also likely to have more parity are more likely to be exposed to the risk factors than their counterparts.

\section{Prevalence and associated factors of HCV among} pregnant women in rural areas of Mwanza city

Regarding HCV seropositivity, the seroprevalence was found to be $0.04 \%$ which is in agreement with previous studies in Sudan and Nigeria [46, 47]. In comparison to previous reports in Egypt, Ivory coast and Rwanda which reported the prevalence of $6.1,3.6$ and $2.4 \%[46,48]$, the reported HCV seroprevalence in this study was significantly low. This could be explained by different methods used in these studies which might significantly differ in sensitivity and specificity. In the current study, the test used has sensitivity and specificity of 98.9 and $99.2 \%$ which might be different from other previous studies. Another possible explanation could be variations in geographical factors which might influence endemicity status in different areas [43, 46, 48-50].

\section{Prevalence and associated factors of HIV seropositivity among pregnant women in rural areas of Mwanza city} In the current study, the prevalence of HIV was found to be $5.0 \%$ which is comparable to a previous study by Manyahi et al. that reported the prevalence of $5.6 \%$ 
Table 6 Univariable and multivariable logistic regression analysis of the factors associated with at least one viral infection among 499 pregnant women attending ANC's in Mwanza rural Tanzania

\begin{tabular}{|c|c|c|c|c|c|}
\hline Characteristics & Viral infection & $\begin{array}{l}\text { Univariable } \\
\text { OR (95\%Cl) }\end{array}$ & $P$ value & $\begin{array}{l}\text { Multivariable } \\
\text { OR (95\%Cl) }\end{array}$ & $P$ value \\
\hline Age & 27[IQR:22-32] & $1.04[1.0-1.08]$ & 0.042 & $1.00[0.94-1.06]$ & 0.918 \\
\hline Parity & $2[\mathrm{QQR}: 1-4]$ & 1.15[1.02-1.29] & 0.016 & & \\
\hline Gestation age & 22[IQR:20-30] & $0.97[0.94-1.00]$ & 0.085 & & \\
\hline Number of sexual partner & $2.5[\mathrm{QQR}: 1-5]$ & $1.03[0.97-1.09]$ & 0.249 & & \\
\hline Age at first sex & 17[IQR:16-19] & $1.01[0.92-1.11]$ & 0.790 & & \\
\hline \multicolumn{6}{|l|}{ Occupation } \\
\hline Employed (143) & 19(13.29\%) & ref & & & \\
\hline Peasant (277) & $50(18.05 \%)$ & $1.44[0.81-2.55]$ & 0.213 & & \\
\hline House wife (79) & $9(11.90 \%)$ & $0.84[0.36-1.95]$ & 0.684 & & \\
\hline \multicolumn{6}{|l|}{ *Education } \\
\hline Secondary (91 & $9(9.89 \%)$ & ref & & & \\
\hline Primary (319) & $50(15.7 \%)$ & $1.69[0.79-3.59]$ & 0.169 & $1.28[0.57-2.83]$ & 0.539 \\
\hline Never attended (89) & $19(21.3 \%)$ & $2.470[0.38-18.1 .05]$ & 0.038 & $1.58[0.63-4.00]$ & 0.330 \\
\hline \multicolumn{6}{|l|}{ Marital status } \\
\hline Married (464) & $27(20.0 \%)$ & ref & & & \\
\hline Not married (35) & $71(15.30 \%)$ & $1.38[0.58-3.29]$ & 0.046 & & \\
\hline \multicolumn{6}{|l|}{ History of genital ulcer } \\
\hline No (471) & $71(15.7 \%)$ & ref & & & \\
\hline Yes (28) & $7(14.9 \%)$ & $0.93[0.40-2.17]$ & 0.884 & & \\
\hline \multicolumn{6}{|l|}{ Genital ulcers } \\
\hline Absent (471) & 74(15.7) & ref & & & \\
\hline Present (28) & $4(14.3)$ & $0.89[0.30-2.65]$ & 0.840 & & \\
\hline \multicolumn{6}{|l|}{${ }^{a}$ History of STIS } \\
\hline No (261) & $35(13.4)$ & ref & & & \\
\hline Yes (238) & $43(18.1)$ & $1.42[0.87-2.31]$ & 0.154 & Omitted & \\
\hline \multicolumn{6}{|l|}{ *Syphilis status } \\
\hline Negative (479) & $70(14.6 \%)$ & ref & & & \\
\hline Positive (20) & $8(40.0 \%)$ & $3.89(1.53-9.87)$ & 0.004 & $3.25[1.23-8.57]$ & 0.016 \\
\hline
\end{tabular}

${ }^{\mathrm{a}}$ Omitted because of collinearity. Syphilis status, education and history of STIs were subjected on multivariable analysis adjusted by age

among pregnant women in urban and rural settings of Tanzania [51]. This observation is also supported by another study by Malima et al. which reported a slight low HIV prevalence $(2.6 \%)$ among pregnant women in rural setting in Northern part of Tanzania [52]. In comparison to HIV prevalence in general population (5.3\%) in Tanzania mainland, the reported prevalence of HIV in the current study is comparable to the general population [19]. These findings indicate that the prevalence of HIV among pregnant women in Tanzania is almost similar between urban and rural settings as well as in general population which could be explained by ongoing interventions on HIV control across the country. In comparison to previous reports in Rwanda and Zambia which documented the prevalence of 25.4 and $24.1 \%$, respectively $[53,54]$, the reported prevalence in the current study is indeed low. The difference could be explained by the fact that the previous studies were perhaps conducted before a wide spread HIV control intervention across the continent. Our findings are also in agreement with other studies in the Sub-Saharan African countries [51, 55, 56] which reported declining trends in HIV among pregnant women population in recent years $[55,57]$.

Among the factors tested, only positive $T$. pallidum serostatus predicted HIV seropositivity among pregnant women in rural settings of Mwanza region which is inconsistent with a previous study [51]. The possible explanation could be sensitivity and specificity of the test used to diagnose $T$. pallidum among these studies. In the current study rapid immunochromatographic test and TPHA were used with sensitivity and specificity of 
$>97 \%$ which could be different from a previous study. Nevertheless, the current study are in agreement with previous studies which reported a significant association between these two infections [58-61]. This could be explained by the fact that HIV and T. pallidum infections shares the same transmission route whereby occurrence of one infection is likely to be influenced by another infection.

In this study despite lower abdominal pain being asked was not included in the analysis of factors and in the definition of history of STIs because it is nonspecific symptom of STIs. This might have underestimated the history of STIs magnitude. In addition, because the recruitment was done during antenatal visits the population did not represent community pregnant women because the ANC attendance is about $73 \%$. Finally, the diagnosis of HSV based on rapid immunochromatographic tests which are not as sensitive as Enzyme Immuno-assays, therefore the prevalence might be underestimated.

\section{Conclusion and recommendations}

In conclusion, a significant proportion of pregnant women in rural settings of Mwanza region is infected with at least one sexually transmitted viral infection which is predicted by positive T. pallidum serostatus. Seroprevalence of HSV-2 IgG antibodies among pregnant women residing in rural areas of Mwanza Tanzania is alarmingly high and is predicted by history of sexual transmitted infections. In addition, HSV-2 IgG seroprevalence in the current study was significantly high among women aged below 20 years compared to those aged above 20 years. Further studies in other areas of Tanzania and studies to establish the outcome of pregnancy in HSV-2 IgM seropositive women in rural population are highly recommended. Moreover, the prevalence of HBV infection among pregnant women in rural areas of Mwanza region is high while the prevalence of $\mathrm{HCV}$ is relatively low compared to other settings. These findings call for the need to strengthen the current antenatal screening protocol by including other viral infections that can potentially results into adverse pregnancy outcomes.

\section{Supplementary information}

Supplementary information accompanies this paper at https://doi.org/10. 1186/s12884-019-2567-1.

Additional file 1. Data collection tool.

\section{Abbreviations}

Cl: Confidence interval; HBsAg: Hepatitis B surface antigen; HBV: Hepatitis B virus; HCV: Hepatitis C virus; HIV: Human immunodeficiency virus; HSV2: Herpes simplex virus - 2; IgG: Immunoglobulin gamma; LICs: Low income countries; OR: Odds ratio

\section{Acknowledgements}

The authors acknowledge the assistance provided by administrative officers and workers at the antenatal clinics involved and the department of Microbiology and Immunology of the Catholic university of Health and allied sciences

\section{Authors' contributions}

MMM and SEM participated in the designing of the study. GN and CC participated in data/sample collection, KVM, DC, FM, VS and BM participated in laboratory analysis of samples, MMM and SEM did data analysis, MMM, MM, GN and SEM participated in data interpretation. MMM wrote the first draft of the manuscript. SEM did the critical review of the manuscript. All authors approved the last version of the manuscript.

\section{Funding}

This study was supported by research funds from CUHAS-Bugando to SEM. The funding body had no role in design of the study, the collection, analysis, and interpretation of data and in writing the manuscript.

\section{Availability of data and materials}

The datasets used and/or analysed during the current study are available from the Director of Research and Publication of the Catholic University of Health and Allied sciences on reasonable request.

\section{Ethics approval and consent to participate}

Prior to the study, official approval to conduct the study was sought from the joint Catholic University of Health and Allied Sciences /Bugando Medical Centre research ethics and review committee with ethical clearance number CREC/274/2018 and permission to conduct the study was sought from District Medical Officers and clinicians stationed at participating district hospitals and health center. Before being enrolled in the study participants were given explanations about the study aims and for those who were opted to participate were asked to give a written informed consent; for those under 18 years were asked to give written assent and also the parents/ guardians provided written consent. For illiterate women, the consent information sheet was loudly explained in Swahili and participants were required to thumb print on the consent form to signify their acceptance to participate. The participants found to have active infection were counseled and linked to the institution that can take care of the infection.

\section{Consent for publication}

Not applicable.

\section{Competing interests}

The authors declare that they have no competing interests.

\section{Author details}

${ }^{1}$ Department of Obstetrics and Gynecology, Bugando Medical Centre, P.O. Box 370, Mwanza, Tanzania. ${ }^{2}$ Department of Microbiology and Immunology, Weill Bugando School of Medicine, Catholic University of Health and Allied sciences, P.O. Box 1464, Mwanza, Tanzania. Institute of Allied Health Sciences, Catholic University of Health and Allied sciences, P.O. Box 1464, Mwanza, Tanzania. ${ }^{4}$ Department of Microbiology and Immunology, Muhimbili University of Health and Allied Sciences, P.O. Box 65001, Dar es Salaam, Tanzania.

Received: 5 January 2019 Accepted: 22 October 2019

Published online: 29 October 2019

\section{References}

1. Mullick S, Watson-Jones D, Beksinska M, Mabey D. Sexually transmitted infections in pregnancy: prevalence, impact on pregnancy outcomes, and approach to treatment in developing countries. Sex Transm Infect. 2005; 81(4):294-302

2. Mirambo MM, Mshana SE, Groß U. Rubella virus, toxoplasma gondii and Treponema pallidum congenital infections among full term delivered women in an urban area of Tanzania: a call for improved antenatal care. Afr Health Sci. 2019;19(2):1858-65.

3. Organization $\mathrm{WH}$ : WHO guidelines for the treatment of genital herpes simplex virus: World Health Organization; 2016.

4. Gupta R, Warren T, Wald A. Genital herpes. Lancet. 2008;370(9605):2127-37. 
5. Wagner H, Van Dyck E, Roggen E, Nunn A, Kamali A, Schmid DS, Dobbins J, Mulder D. Seroprevalence and incidence of sexually transmitted diseases in a rural Ugandan population. Int J STD AIDS. 1994;5(5):332-7.

6. Brown ZA, Selke S, Zeh J, Kopelman J, Maslow A, Ashley RL, Watts DH, Berry $S$, Herd M, Corey L. The acquisition of herpes simplex virus during pregnancy. N Engl J Med. 1997;337(8):509-16.

7. Eskild A, Jeansson S, Jenum P. Antibodies against herpes simplex virus type 2 among pregnant women in Norway. Tidsskrift for den Norske laegeforening: tidsskrift for praktisk medicin, ny raekke. 1999;119(16):2323-6.

8. UNAIDS. Joint United Nations Programme on HIV/AIDS, Progress report on the global plan towards the elimination of new infections among children by 2015 and keeping their mothers alive. Geneva: UNAIDS; 2014.

9. Fawzi W, Msamanga G, Spiegelman D, Renjifo B, Bang H, Kapiga S, Coley J, Hertzmark E, Essex M, Hunter D. Transmission of HIV-1 through breastfeeding among women in Dar es Salaam, Tanzania. J Acquir Immune Defic Syndr (1999). 2002;31(3):331-8.

10. Teresa L, Wright M. Introduction to chronic hepatitis B infection. Am J Gastroenterol. 2006;101:S1-6.

11. Zaltron S, Spinetti A, Biasi L, Baiquera C, Castelli F. Chronic HCV infection: epidemiological and clinical relevance. BMC Infect Dis. 2012;12(2):S2.

12. MacLachlan JH, Cowie BC. Hepatitis B virus epidemiology. Cold Spring Harb Perspect Med. 2015;5(5):a021410.

13. Zanetti A. Global surveillance and control of hepatitis C. report of a WHO consultation organized in collaboration with the viral hepatitis prevention board, Antwerp, Belgium. J Viral Hepat. 1999;6(1):35-47.

14. Madhava V, Burgess C, Drucker E. Epidemiology of chronic hepatitis C virus infection in sub-Saharan Africa. Lancet Infect Dis. 2002;2(5):293-302.

15. Ward H, Mertens TE, Thomas C. Health seeking behaviour and the control of sexually transmitted disease. Health Policy Plan. 1997;12(1):19-28.

16. NBS: Population Distribution by Age and Sex. 2012.

17. Macro II: Tanzania demographic and health survey 2010. 2011.

18. Inc Jwas: Kish, leslei. Survey sampling new York 1965.

19. MOHCDGEC. National Guidelines for the management of HIV and AIDS -National AIDS Control Programme. 6th ed; 2017. p. 1.

20. WHO. Sexually transmitted infections (STIS): the importance of a renewed commitment to STI prevention and control in achieving global sexual and reproductive health. WHO: World Health Organization; 2012.

21. Hokororo A, Kihunrwa A, Hoekstra P, Kalluvya SE, Changalucha JM Fitzgerald DW, Downs JA. High prevalence of sexually transmitted infections in pregnant adolescent girls in Tanzania: a multi-community cross-sectional study. Sex Transm Infect. 2015;91(7):473-8.

22. Anjulo AA, Abebe T, Hailemichael F, Mihret A. Seroprevalence and risk factors of herpes simplex virus-2 among pregnant women attending antenatal care at health facilities in Wolaita zone, Ethiopia. Virol J. 2016; 13(1):43.

23. Domercant JW, Louis FJ, Hulland E, Griswold M, Andre-Alboth J, Ye T, Marston BJ. Seroprevalence of herpes simplex virus type-2 (HSV-2) among pregnant women who participated in a national HIV surveillance activity in Haiti. BMC Infect Dis. 2017;17(1):577.

24. Smith JS, Robinson NJ. Age-specific prevalence of infection with herpes simplex virus types 2 and 1: a global review. J Infect Dis. 2002; 186(Supplement_1):S3-S28.

25. Munjoma MW, Kurewa EN, Mapingure MP, Mashavave GV, Chirenje MZ, Rusakaniko S, Hussain A, Stray-Pedersen B. The prevalence, incidence and risk factors of herpes simplex virus type 2 infection among pregnant Zimbabwean women followed up nine months after childbirth. BMC Womens Health. 2010;10(1):2

26. Suligoi B, Cusan M, Santopadre P, Palù G, Catania S, Girelli G, Pala S, Vullo V. HSV-2 specific seroprevalence among various populations in Rome, Italy. Sex Transm Infect. 2000;76(3):213-4.

27. Biswas D, Borkakoty B, Mahanta J, Walia K, Saikia L, Akoijam BS, Jampa L, Kharkongar A, Zomawia E. Seroprevalence and risk factors of herpes simplex virus type-2 infection among pregnant women in Northeast India. BMC Infect Dis. 2011;11(1):325

28. Nilsen A, Mwakagile D, Marsden H, Langeland N, Matre R, Haarr L. Prevalence of, and risk factors for, HSV-2 antibodies in sexually transmitted disease patients, healthy pregnant females, blood donors and medical students in Tanzania and Norway. Epidemiol Infect. 2005;133(5):915-25.

29. Msuya SE, Mbizvo E, Hussain A, Sam NE, Jeansson S, Stray-Pedersen B. Seroprevalence and correlates of herpes simplex virus type 2 among urban Tanzanian women. Sex Transm Dis. 2003;30(7):588-92.
30. Yahya-Malima KI, Evjen-Olsen B, Matee MI, Fylkesnes K, Haarr L. HIV-1, HSV-2 and syphilis among pregnant women in a rural area of Tanzania: prevalence and risk factors. BMC Infect Dis. 2008:8(1):75.

31. Brown JM, Wald A, Hubbard A, Rungruengthanakit K, Chipato T, Rugpao S, Mmiro F, Celentano DD, Salata RS, Morrison CS. Incident and prevalent herpes simplex virus type 2 infection increases risk of HIV acquisition among women in Uganda and Zimbabwe. Aids. 2007;21(12):1515-23.

32. Corey L, Kapiga SH, Sam NE, Bang H, Quanhong N, Ao TT, Kiwelu I, Chiduo $\mathrm{S}$, Ndibe $U$, Seage $\mathrm{G}$. The role of herpes simplex virus type 2 and other genital infections in the acquisition of HIV-1 among high-risk women in Northern Tanzania. Commentary. J Infect Dis. 2007;195(9):1260-9.

33. Mirambo MM, Mbena PB, Mushi MF, Mtebe M, Moremi N, Seni J, Mshana SE. Prevalence of Hepatitis B surface antigen among pregnant women attending antenatal clinic at Nyamagana District Hospital Mwanza, Tanzania. Tanzan J Health Res. 2016;18(1).

34. Panga B. Seroprevalence of hepatitis b surface antigen and associated factors among pregnant women attending antenatal care clinic in Moshi municipality, Kilimanjaro region 2012. WHO: Muhimbili University of Health and Allied Sciences; 2012.

35. Shah HBU, Dar MK, Jamil AA, Atif I, Ali RJ, Sandhu AS, Usmani AQ. Knowledge, attitudes and practices of hepatitis $B$ and $C$ among barbers of urban and rural areas of Rawalpindi and Islamabad. J Ayub Med Coll Abbottabad. 2015:27(4):832-6.

36. Shalaby S, Kabbash I, El Saleet G, Mansour N, Omar A, El Nawawy A. Hepatitis B and C viral infection: prevalence, knowledge, attitude and practice among barbers and clients in Gharbia governorate, Egypt; 2010.

37. Chaudhry MA, Rizvi F, Ashraf MZ, Afzal M, Niazi S. Knowledge and practices of barbers regarding hepatitis B and hepatitis C in Bahra Kahu, IslamabadPakistan. Rawal Med J. 2010;35(1):37-40.

38. MacLean B, Hess RF, Bonvillain E, Kamate J, Dao D, Cosimano A, Hoy S. Seroprevalence of hepatitis $B$ surface antigen among pregnant women attending the Hospital for Women \& Children in Koutiala, Mali. S Afr Med J. 2012;102(1):47-9.

39. Wurie I, Wurie A, Gevao S. Sero-prevalence of hepatitis B virus among middle to high socio-economic antenatal population in Sierra Leone. West Afr J Med. 2005:24(1):18-20.

40. Collenberg E, Ouedraogo T, Ganamé J, Fickenscher H, Kynast-Wolf G, Becher $H$, Kouyaté B, Kräusslich HG, Sangaré L, Tebit DM. Seroprevalence of six different viruses among pregnant women and blood donors in rural and urban Burkina Faso: a comparative analysis. J Med Virol. 2006;78(5):683-92.

41. Mbaawuaga E, Enenebeaku M, Okopi J. Hepatitis B virus (HBV) infection among pregnant women in Makurdi, Nigeria. Afr J Biomed Res. 2008;11(2).

42. Okoth F, Mbuthia J, Gatheru Z, Murila F, Kanyingi F, Mugo F, Esamai F, Alavi Z, Otieno J, Kiambati H. Seroprevalence of hepatitis B markers in pregnant women in Kenya. East Afr Med J. 2006;83(9):485-93.

43. Elsheikh RM, Daak AA, Elsheikh MA, Karsany MS, Adam I. Hepatitis B virus and hepatitis C virus in pregnant Sudanese women. Virol J. 2007;4(1):104.

44. Mwambe B, Mirambo MM, Mshana SE, Massinde AN, Kidenya BR, Michael D, Morona D, Majinge C, Groß U. Sero-positivity rate of rubella and associated factors among pregnant women attending antenatal care in Mwanza, Tanzania. BMC Pregnancy Childbirth. 2014;14(1):95.

45. Chibwe E, Mirambo MM, Kihunrwa A, Mshana SE. Magnitude of the Cytomegalovirus infection among pregnant women attending antenatal clinics in the city of Mwanza, Tanzania. BMC Res Notes. 2017;10(1):489.

46. Mutagoma M, Balisanga $H$, Sebuhoro D, Mbituyumuremyi A, Remera E, Malamba SS, Riedel DJ, Nsanzimana S. Hepatitis C virus and HIV co-infection among pregnant women in Rwanda. BMC Infect Dis. 2017;17(1):167.

47. Esan A, Omisakin C, Ojo-Bola T, Owoseni M, Fasakin K, Ogunleye A. Seroprevalence of hepatitis B and hepatitis $C$ virus co-infection among pregnant women in Nigeria. Am J Biomed Res. 2014;2(1):11-5.

48. Khamis HH, Farghaly AG, Shatat HZ, El-Ghitany EM. Prevalence of hepatitis C virus infection among pregnant women in a rural district in Egypt. Trop Dr. 2016:46(1):21-7.

49. Umumararungu E, Ntaganda F, Kagira J, Maina N. Prevalence of hepatitis C virus infection and its risk factors among patients attending Rwanda military hospital, Rwanda. BioMed Research Int. 2017;2017:5841272.

50. Rouet F, Chaix ML, Inwoley A, Msellati P, Viho I, Combe P, Leroy V, Dabis F, Rouzioux C. HBV and HCV prevalence and viraemia in HIV-positive and HIVnegative pregnant women in Abidjan, Côte d'Ivoire: the ANRS 1236 study. J Med Virol. 2004;74(1):34-40. 
51. Manyahi J, Jullu BS, Abuya MI, Juma J, Ndayongeje J, Kilama B, Sambu V, Nondi J, Rabiel B, Somi G. Prevalence of HIV and syphilis infections among pregnant women attending antenatal clinics in Tanzania, 2011. BMC Public Health. 2015;15(1):501.

52. Yahya-Malima KI, Olsen BE, Matee MI, Fylkesnes K. The silent HIV epidemic among pregnant women within rural northern Tanzania. BMC Public Health. 2006;6(1):109

53. Leroy V, Ntawiniga P, Nziyumvira A, Kagubare J, Salamon R. HIV prevalence among pregnant women in Kigali Rwanda. Lancet. 1995;346(8988):1488-9.

54. Makasa M, Fylkesnes K, Michelo C, Kayeyi N, Chirwa B, Sandoy I. Declining syphilis trends in concurrence with HIV declines among pregnant women in Zambia: observations over 14 years of national surveillance. Sex Transm Dis. 2012;39(3):173-81.

55. Eaton JW, Rehle TM, Jooste S, Nkambule R, Kim AA, Mahy M, Hallett TB. Recent HIV prevalence trends among pregnant women and all women in sub-Saharan Africa: implications for HIV estimates. AIDS (London, England). 2014;28(4):S507.

56. Kabera R, King L. The prevalence of HIV infection among pregnant women at Kabutare District hospital-Rwanda. East Cen Afr J Surg. 2013;18(3):89-93

57. Manyahi J, Jullu BS, Abuya MI, Juma J, Kilama B, Sambu V, Nondi J, Rabiel B, Makyao N, Ramadhani A. Decline in the prevalence HIV among pregnant women attending antenatal clinics in Tanzania, 2001-2011. Tanzan J Health Res. 2017;19(2).

58. Mutagoma M, Balisanga H, Remera E, Gupta N, Malamba SS, Riedel DJ, Nsanzimana S. Ten-year trends of syphilis in sero-surveillance of pregnant women in Rwanda and correlates of syphilis-HIV co-infection. Int J STD AIDS. 2017;28(1):45-53.

59. Lawi JD, Mirambo MM, Magoma M, Mushi MF, Jaka HM, Gumodoka B, Mshana SE. Sero-conversion rate of syphilis and HIV among pregnant women attending antenatal clinic in Tanzania: a need for re-screening at delivery. BMC Pregnancy Childbirth. 2015;15(1):3.

60. Msuya SE, Uriyo J, Hussain A, Mbizvo EM, Jeansson S, Sam NE, StrayPedersen B. Prevalence of sexually transmitted infections among pregnant women with known HIV status in northern Tanzania. Reprod Health. 2009;6(1):1.

61. Temmerman M, Ali FM, Ndinya-Achola J, Moses S, Plummer FA, Piot P. Rapid increase of both HIV-1 infection and syphilis among pregnant women in Nairobi, Kenya. AIDS (London, England). 1992;6(10):1181-5.

\section{Publisher's Note}

Springer Nature remains neutral with regard to jurisdictional claims in published maps and institutional affiliations.

Ready to submit your research? Choose BMC and benefit from:

- fast, convenient online submission

- thorough peer review by experienced researchers in your field

- rapid publication on acceptance

- support for research data, including large and complex data types

- gold Open Access which fosters wider collaboration and increased citations

- maximum visibility for your research: over $100 \mathrm{M}$ website views per year

At BMC, research is always in progress.

Learn more biomedcentral.com/submissions 